$A D D I N$, Volume 12, Number 2, Agustus 2018

\title{
ISLAM NUSANTARA IN POLITICAL CONTESTATION IDENTITY RELIGION IN INDONESIA
}

\section{Muh. Khamdan}

Universitas Islam Negeri (UIN) Syarif Hidayatullah Jakarta

khamdanwi@gmail.com

\section{Wiharyani}

Universitas Indonesia

wihar2@gmail.com

\section{Abstract}

The relationship between the religion represented by Islam and the State that is represented by the democratic political system continues remain to be a problem. Ideological debates that Islamic law should be implemented and escorted through Islamic countries experiencing resistance against groups who argued that Islam is a substance that is in compliance with democracy. Religious ideology has often been a motivation to justify the struggle through the violence that has been done. Strengthening of violence in the name of religion is regarded as a form of struggle for bottomic beliefs and religious form in kaffah. Nationalism of Islamic religion Leaders by receiving Pancasila as the Indonesian ideology its been a moderate wisdom that has taken to maintain the unity of Indonesia, while keeping the existence of religions living. The relationship of religion and the State by Islamic religion Leaders of Nahdhatul Ulama (NU) considered 
as a mutual-connection with maintaining Indonesian nationalism without discriminating treatment of religions, tribes, and inter-group relations is face Islam Nusantara in Indonesia. Politics as the source of radicalism muted by NU leaders with a fatwa that receiving of Pancasila both as the nations foundation and as a spirit of Islam Nusantara. This research uses psychology politics theory and the theory of social identity's approach that analyzing potential radicalism in society.

Keywords: Democracy, Nationalism, Pancasila, Ideology, Islam Nusantara.

\section{Abstrak}

Hubungan antara agama yang diwakili oleh Islam dan negara yang diwakili dengan sistem politik demokrasi masih terus menjadi masalah. Perdebatan ideologi bahwa bukum Islam harus dilaksanakan dan dikawal melalui negara Islam mengalami perlawanan dengan kelompok yang berpandangan bahwa Islam adalah substansi yang sudah sesuai dengan demokrasi. Ideologi keagamaan sering menjadi motivasi untuk membenarkan perjuangan melalui aksi kekerasan yang dilakukan. Penguatan kekerasan atas nama agama dianggap sebagai bentuk perjuangan keyakinan yang sangat mendasar dan wujud beragama secara kaffah. Nasionalisme ulama dengan menerima Pancasila sebagai dasar negara Indonesia merupakan sikap tengah yang diambil untuk menjaga persatuan Indonesia, sekaligus menjaga keberlangsungan beragama. Relasi agama dan negara oleh ulama-ulama Nahdhatul Ulama (NU) dianggap dalam hubungan akomodatif dengan mempertahankan nasionalisme Indonesia tanpa membedakan agama, suku, dan golongan merupakan wajah Islam Nusantara di Indonesia. Politik sebagai sumber radikalisme diredam oleb ulama NU dengan fatwa penerimaan terbadap Pancasila sebagai dasar negara sesuai dengan semangat Islam Nusantara. Penelitian ini menggunakan pendekatan teori psikologi politik dan teori identitas sosial dalam menganalisis potensi radikalisme di masyarakat.

Kata Kunci: Demokrasi, Nasionalisme, Pancasila, Ideologi, Islam Nusantara. 


\section{A. Introduction}

The relationship between the religion represented by Islam and the State that is represented by the democratic political system still continues to be a problem. Ideological debate that Islamic law should be implemented and escorted through Islamic countries experiencing resistance groups who argued that Islam is a substance that is in compliance with democracy. Failure to marry (bringing together) Islam and democracy at least apparent from the failure of the Arab Spring originally wanted to do a change of dictatorship regime ${ }^{1}$ but instead gave birth to the long conflict in the various countries of the Middle East.

Religious ideology is often a motivation to justify the struggle through the violence that was done. Strengthening of violence in the name of religion is regarded as a form of struggle for a very basic beliefs and religious form in kaffah. Religion is often used as a factor of legitimacy or to cover the conflict. ${ }^{2}$ Religion can influence the emergence of extremism because religion can be in two polar opposites, that felt more right or more right to enter Heaven as well as the existence of a revenge of history in every development. ${ }^{3}$ Al-Jabiri confirms that violence extremism is no more than a phenomenon that arises from socio-political issues, then packed with religious issues. ${ }^{4}$ The political attitude of religious extremism as it was originally performed on the order of belief under the slogan of religious purification, but eventually developed in the field

${ }^{1}$ Mark L. Haas dan David W. Lesch, The Arab Spring Change and Resistance in the Middle East (Boulder Colorado: Westview Press, 2013),

${ }^{2}$ Muh. Khamdan, Bina Damai Terorisme (Kudus: Parist, 2015), 40.

${ }^{3}$ Mark Jurgensmayer, Terror in the Mind of God: The Global Rise of Religious Violence (California: University of California Press, 2001), 14-15; James M. Lutz dan Brenda J. Luts, Global Terrorism (London: Routledge, 2004), 74-78.

${ }^{4}$ Muhammad 'Abid al-Jābiri, Qadaya al-Fiker al-'Aräbi: al-Mas-alah al-Thaqäfiyyah (Beirut: Markaz Dirâsah al-Wahidah al-'Arābiyyah, 1994), 134-135. 
of law via the pattern of an understanding with the religious doctrine of the text.

The political attitude of religion without connecting with the socio-cultural context of societal certainly influential on the model of religion intolerant and does not respect human rights. The growing diversity of expression along with the political establishment charges the Islamic State as the influence of transnational movements that have no awareness of local wisdom and the rejection of the concept of the nation State.

A person or group who perform acts of extreme violence regardless of their actions as a crime, but rather emerged a sense of pride for being the troops who fought for the truth that he believes. ${ }^{5}$ Extremism groups which later developed into a transnational movement often uses symbols in the military organization of his movement, ${ }^{6}$ such as the Irish of Republican Army (IRA) in Ireland, Euskadi Ta; (ETA) in Spain, Hezbollab in Lebanon, Arabic diacritics al-Muqawwama alIslamiyya (Hamas) in the Palestinian territories, the Front Islamique du Salut (FIS) in Algeria, the Fuerzas Armadas Revolucionarias de Colombia (FARC) in Colombia, The Moro National Liberation Front (MNLF) and Abu Sayyaf's Group (ASG) in the Philippines, Al-Qaeda and the Taliban in Afghanistan, as well as ad-Dawlah alIslamiyah fil Iraq wa Sham or known as ISIS. ${ }^{7}$

Extremism is a manifestation of the action of radicalism. Radicalism as a kind of pragmatism is not always marked by violent actions, but can also be limited to thoughts

${ }^{5}$ Imam Samudra, Aku Melawan Terorisme (Solo: al-Jazera, 2004), 114-115; Asep Adisaputra, Imam Samudra Berjïhad, Cet. 1 (Jakarta: Grafika Indah, 2006), 62-69; Wawan H. Purwanto, Terorisme Ancaman Tiada Akhir: Bahaya dan Strategi Pemberantasan di Indonesia, Cet. II (Jakarta: Grafindo Khazanah Ilmu, 2004), 53-55.

${ }_{6}^{6}$ Anisseh Van Engeland dan Rachael M. Rudolph, From Terrorism to Politics (Ethics and Global Politics) (Burlington: Ashgate Publishing Company, 1988).

7 Reno Muhammad, ISIS: Mengungkap Fakta Terorisme Berlabel Islam (Jakarta Selatan: Noura Books, 2014), 32. 
and ideologies that do not use violent means in carrying out these thoughts. he potential of radicalism that is determined by the individual's perception of course not only affected a certain ideological grounding, but can also be influenced by a variety of other factors in global issues, regional and locality. The action of terrorism which took place in Indonesia for example, preceded the existence of ideological fanaticism so consider the other wrong and led to the use of weapons or bombing as a form of endorsement any ways or extreme.

Transnational Islamic movement is the group that its activities cross the line of the territorial nation State to realize its goals. The movement's militancy has various variants of the purpose and the struggle in accordance with social aspects influenced history in countries of its founding. Pan-Islamism movement and the Muslim Brotherhood (Ikhwanul Muslimin) in Egypt, Hizb ut Tahrir in Lebanon, Jama'ah Tabligh in India and other Islamic movements inspired by the resistance of a people weak and colonialism. The struggles of transnational Islamic movement is often accompanied by the presence of the process of criticizing and blaming among different religious practices. Culture deemed not of Islam has been blamed and should be eliminated with the war thought (ghazw al-fikr). The potential diversity of life that form a pattern of black and white or false actually started having periods of growth along with the climate that guarantees the freedom of democracy.

The Government has built partnerships with the scholars through a variety of approaches to the Elimination of radical ideology that teaches extremism flourished in Indonesia. National Islamic developing in Indonesia has become the pilot shaft that religion and democracy can be integrated and peaceful walk. Islam does not accommodate practices violence but develop moderation (tawasuth) and 
balance (wasathiyah). Therefore, religious extremism is not just a question of theological and religious interpretation, but many external factors that tend to dominate in the relation between religion and democracy globalization.

\section{B. The Phenomenon of Transnational Movement in Indonesia}

Contestation of ideas between nationalism and religion always leads to two main issues, namely the relation of muslim versus non-Muslims and law of God versus law of man. The Foundation should be built is the realization that Islam as a religion of humanity. Religious ideology has often been a motivation to justify the struggle through the violence that has been done. The political attitude of religion without connecting with the socio-cultural context of societal certainly influential on the model of religion intolerant and does not respect human rights. The growing diversity of expression along with the political establishment charges the Islamic State as the influence of transnational movements that have no awareness of local wisdom and the rejection of the concept of the nation State.

Organization of the radical movement to build an international network of transnational nature because these groups have is global leadership, working in a network of cross country and the continent, as well as carrying the same ideals to re-establish the ideal Islamic leadership in the form of a khilafah, or Islamic State. Some of the things which aspects influenced is the fact upon the suffering of Muslims in different countries due to colonialism the West against muslim countries as well as countries with a majority muslim population. Jamal Al-Afghany e.g. arouse patriotism 
on the basis of religious solidarity called Pan Islamism. ${ }^{8}$ The Islamic movement that is transnational understanding Islam in monolithic and reject the variants of Islam considered tainted because so that needs to be purified back. ${ }^{9}$

In line with the rise in international relations who woke up between indigenous Malay Archipelago with other countries, the exchange of good character as Ambassador of the Kingdom as well as among the educated to learn and teach is the fact who cannot be ruled out. The relationship gave rise to complex intellectual genealogy, and further strengthened by the bonds of spiritual sufi orders form teacher or murshid and his students. ${ }^{10}$ The development of muslim societies commensurate Hajj command in the pillars of Islam, influenced the number of muslim Indonesia go to Makkah and start interacting with the teachings of Islamic purification that wants Wahhābiyah without mazhab or without the adoption of a culture that tends to be a heresy (bid'ab), superstition (tahayu), and khurafat.

The influence of transnational ideology that leads to a movement of religious radicalism in Indonesia started in the Padri in Group Policy. Haji Miskin from Lu (h) ak Agam, Haji Abdur Rahman from Piobang Limah Puluh Kota, and Haji Muhammad Arief from Sumanik Batusangkar, upon his return home from Mecca in the period between 1803 and 1804, forming groups to perform purification Padri keberagamaan Minangkabau society from cultural contamination and customs that are considered incompatible

${ }^{8}$ Ahmad Mansur Suryanegara, Api Sejarah (Bandung: Grafindo Media Pratama, 2013), 251.

${ }^{9}$ Abdurrahman Wahid (Ed), Ilusi Negara Islam: Ekspansi Gerakan Islam Transnasional di Indonesia (Jakarta: Gerakan Bhineka Tunggal Ika, The Wahid Institute dan Maarif Institute, 2009), 43.

${ }^{10}$ Andree Feillard, NU vis-à-vis Negara: Pencarian Isi, Bentuk, dan Makna (Yogyakarta: LKiS, 1995), 3; Azyumardi Azra, Jaringan Ulama Timur Tengah dan Kepulauan Nusantara Abad XVII dan XVIII, Cet. I (Bandung: Penerbit Mizan, 1994), 45. 
with the teachings of the Quran. ${ }^{11}$ Haji Miskin together figures of the Group's armed forces deploy in the Padri attempts of religious purification, as do the Arabs in the Wahabi House collaborated with the military forces of Al-Sa'ùd since 1744 for control of the peninsula of Arabia. ${ }^{12}$ Movement changes made Haji Miskin and Padri gets hard challenge from teachers of Shattariyah because of movement that carried out violent measures and tend to choose judgement someone as an Infidel or misdirection upon conviction of others.

Padri movement other scholars claimed easy as perverse as my master Nan Renceh Nan Tuanku Tuo, hostile to his own, and hostile to those who don't think the same. Tuanku Nan Renceh also sentenced her aunt himself who has aged and not allow to bury his body but was banished to the forest because of the chewing of betel prohibited among the Wahabi. ${ }^{13}$ The violence that was done the Padri e.g., assault and murder of Royal family of Pagaruyung, flat land. The Kingdom that had been converted to Islam since the 16th century it was attacked the Padri in 1809. Tuanku Lelo as one of the leaders of the Group of Padri mentions the Royal family Tuanku Rajo Naro at Talang, Islam does not run correctly, and are considered infidels. The bloody tragedy occurred in 1815, Padri movement under the leadership of Tuanku Lintau killing family Pagaruyung so ignite Padri War en masse.

Religious purification movement that accompanied the violence by the Padri to revamp the political system at the

${ }^{11}$ Amir Sjarifudin TJ, Minangkabau Dari Dinasti Iskandar Zulkarnain Sampai Imam Bonjol (Jakarta: Gria Media Prima, 2014), 514.

${ }^{12}$ Khaled Abou El-Fadl, Selamatkan Islam dari Muslim Puritan (Jakarta: Serambi, 2005), 80-81.

${ }^{13}$ Mangaraja Onggang Parlindungan, Pongkinangolngolan Sinambela Gelar Tuanku Rao: Teror Agama Islam Mą̧bab Hambali di Tanab Batak. 1816-1833, (Yogyakarta: LKiS, 2007), 132. 
same time the tradition of the Minangkabau society, diversity can be referred to as a group of fundamental salafisme ${ }^{14}$ revolutionary. Such an approach based on Grant Wardlaw in understanding violence perpetrated between the civilians with the State. ${ }^{15}$ Angel Rabasa approach based on the source of Islamic radicalism, influenced the existence of centralizing the Padri movement of religious authority. ${ }^{16}$

Olivier Roy explains that religious fundamentalism is often turned into radical action to reform society through political power. ${ }^{17}$ Measures such as re interpretation motion experienced a radical form of resistance in different regions against the Kingdom of the Netherlands Protestants colonized Indonesia, namely Lampung War (1832-1833) led by Imba Koesoema, Banjarmasin War (1859-1905) led by Prince Antasari, Batak war (1872-1907) led Si Singamangaradja XII, the Aceh War (1873-1914) led a joint Cut Nyak Teuku Umar Din, and the Java war in various places. ${ }^{18}$

The political changes of the Sultanate of Ottoman Turkey became a secular Republic of Turkey by Mustafa Kemal Atartuk on 3 March 1924 resulted in a reduction of the influence of Pan-Islamism movement. The State is backed by the fall of King Husein Ali and King who embraced Islam Expert Sunnah Wal Jamaah as King of the Hejaz by the revolt of Muhammad's family invested with Sa'ud bin Abdul Aziz as King supported the Anglican Kingdom

${ }^{14}$ Nazih Ayubi, Political Islam: Religion and Politics in the Arab World (London and New York: Routledge, 1991), 67.

${ }^{15}$ Grant Wardlaw, Political Terrorism (New York: Cambridge University Press, 1986), 14-15.

${ }^{16}$ Angel M. Rabasa, The Muslim World After 9/11 (Arlington: The RAND Corporation, 2004), 36.

${ }^{17}$ Olivier Roy, Genealogi Islam Radikal (Yogyakarta: Genta Press, 2005), 13.

${ }^{18}$ Ahmad Mansur Suryanegara, API Sejarah, cet. 6 (Bandung: Grafindo Media Pratama, 2013), 234-270. 
of England. ${ }^{19}$ The dominance of wahabi movement ruled Makkah make intellectual networks of scholars and students from Indonesia experienced conflict due to different political ideology as the formation of the religious Committee of the Hijaz on 31 January 1926 by the cleric in Indonesia Jamaah Ahlussunnah Wal which later became the organization called Nahdlatul Ulama. ${ }^{20}$ Committee of the Hijaz formed KH. Abdul Wahab Chasbullah aims to ask King Saud gave the freedom of running the four schools of jurisprudence teaching in Mecca and Medina, as well as dismantling the mausoleum of Prophet and historic places in Islam.

The denial system of Government after the independence of Indonesia carried out by armed civilian movement Darul Islam/Tentara Islam Indonesia (DI/TII). The movement led by Kartosoewiryo Maridjan Sekarmadji wants to establish an Islamic State with the proclaimed Islamic State Indonesia (NII) on August 7, 1949 in the village of Cisampah, Ciawiligar, Tasikmalaya. The uprising ended after Kartosoewiryo NII was arrested on June 3, 1962 through operation off the Pagar Besi posse region communication guerrillas with the community. Death is not turned away, the sustainability of Kartosoewiryo movement from the central character of ex- Darul Islam or Soldiers Islam of Indonesia (DI/TII) to keep fighting for the Islamic State of Indonesia.

Many former members who then supported the Golkar after a political approach by the Government, but many also refused so as to make the two factions. In the faction as Fillah refused to do the jihad armed resistance led

${ }^{19}$ Abdul Aziz, Chiefdom Madinah: Salah Paham Negara Islam (Jakarta: Pustaka Alvabet, 2011), xviii; Zuhairi Misrawi, Madinab: Kota Suci, Piagam Madinah, dan Teladan Muhammad SAW (Jakarta: Penerbit Buku Kompas, 2009), 270-271.

${ }^{20}$ Ali Maschan Moesa, Nasionalisme Kiai: Konstruksi Sosial Berbasis Agama (Jogjakarta: LKiS, 2007), 131. 
by Djaja Sudjadi, Adah Djaelani Tirtapraja, Ateng Djaelani, and Danu Muhammad Hasan. On the factions in Fisabilillah led by Ahmad Sobari, the continued spirit of Kartosoewiryo to establish the Islamic State of Indonesia (NII), thus leading to radical action and later called terrorism. The failure of the NII to establish Darul Islam is experiencing a new form of organization that allows doing the resistance weapons, namely the Jama'ah Islamiyah (JI). ${ }^{21}$ This resistance movement utilizing situation of freedom of democracy in Indonesia, so the figures in the ex DI/TII or JI activists who came from Indonesia to build the new power networks.

Islamic reform movement which was originally declared Islam as a cause of the decline of classical Islam, the switch target to reconstruct the repeated political ideology. The movement go hand in hand development of contemporary jihadi ideology which influenced the thought of Sayyid Qutb. ${ }^{22}$ Qutb's thought as quoted As'ad, dividing the community over two (2) groups, namely the community ignorance who do challenge the laws of God and the Islamic community who apply the laws of God (al-Ḥakimiyyah lillāh). The setbacks faced by Muslims in various countries, economic decline, dai begins to reign, and morality of society seems to get an answer because culture and ignorance as a result of not implementing the law in the form of Islamic law as a whole.

Such thinking implies penegasian all that is not of God, and not of God, polytheists, perverted Heathens, and tyrants. According to Islamic fundamentalism is among the Union between religion, the world, and the country (dīn, dunyā,

${ }^{21}$ Rohan Gunaratna, Inside Al-Qaeda, Global Network of Terror (New York: Columbia University Press, 2002).

${ }^{22}$ As'ad Said Ali, Al-Qaeda: Tinjanan Sosial-Politik, Ideologi dan Sepak. Terjangnya (Jakarta: LP3ES, 2014), 16-17. 
dawlah), so the need for the establishment of an Islamic State led by a khālifah to be over religion are pure and kāffah. ${ }^{23}$ The movement is run by Hizb ut Tahrir powered Taqiyuddīn an-Nabhānī in Syria, Lebanon, and Jordan in 1953, and has been declared an illegal organization in the country of origin on the stand. The embryo of the prohibited Hizb ut Tahrir rearm in Indonesia with the Organization Hizb ut Tahrir Indonesia (HTI).

The transformation of thought Qutb Al-Habshi inspires Muslims led by Shukri Musthofa, Worshipers Jihad or Jihad Tanzimul Mohammed Abdul Aziz Al-Sayqawi Ismail Thanthawi together, and Jemaah Islamiyah, Umar initiated Abdurrahman, concrete action to do implement al-Hakimiyyah lillāh to replace the law of pagan ignorance. ${ }^{24}$ Concrete steps replacing the rule of infidels is a must and the fight became a liability as understanding of the Surat Al-Anfal Verse 44. The war against the infidel Government includes also expel the infidels from Muslim lands for being the cause of destruction of the religion of Islam. ${ }^{25}$ Opinions developed by Abdullah Azzam, a Palestinian descent Jordan scholars, this experience influenced the jihad in Afghanistan against the Soviet Union and traumatic war over Palestine with Israel. According to Azzam Jihad is the only way to fight for and become a permanent obligation Fard ain " that is because Islam with the sword upright and more mainstream than the obligation of prayer, fasting, or Hajj.

The development of democratization in Indonesia increasingly facilitate the activists of Jemaah Islamiyah to

${ }^{23}$ Taqiyuddīn an-Nabhānī, Daulah Islam, Terj. Umar Faruq (Jakarta Selatan: HTI Press, 2009), 273.

${ }^{24}$ Abdul Mun'im al-Hafni, Ensiklopedia Golongan, Kelompok, Aliran, Maح̧ab, Partai dan Gerakan Islam (Jakarta: Grafindo, 1999), 318.

${ }^{25}$ Abdullah Azzam, Runtubnya Khilafah dan Upaya Menegakkannya (Solo: Pustaka Al-Haq, 2002), 158. 
conduct terror actions, what appeared a fatwa from Osama bin Laden which allows attacks to civilians, especially citizens of the United States as a action reply (retaliation). ${ }^{26}$ Relationship with terror activities materialize the fatwa after appearing against bomb explosion 15 churches in several areas in Indonesia on Christmas Eve 2000. Operation terror so obviously very well-planned and fall into the category of military operations by the Al-Qaeda network and the Jama'ah Islamiyah in Indonesia.

The mobilization of the radical movement of cells conducted by Indonesia with Dulmatin support Abu Bakar Ba'asyir as Jemaah Ansharut amir Tawheed (JAT) through military training in the hills Janto, Aceh Besar, in July 2009. Cadres from various groups joined, such as the JAT group, Dulmatin, Banten Ring as part of a faction in West Java, factions in the Mujahideen, the gift of Water compact, Tawhid wal Jihad, Mujahideen, NII ex Lampung, and alumni conflict Poso. ${ }^{27}$ Police were able to unravel the network of cross-country terrorism training on February 22, 2010, causing separation of the radical action of fugitive terrorism throughout Indonesia.

Sigit Qardhawi with group of Hisbah was shot by Densus 88 on May 15, 2011, Abu Roban shot in the trunk with the Western Indonesia Mujahideen terrorist group (MIB), Sadana Fadli was caught in a Bank robbery CIMB Medan, and Santoso alias Abu Wardah with Eastern Indonesia Mujahideen terrorist group (MIT). Failure to build network centers in Aceh, making training center moved to Poso with the advent of terrorism networks MIT Chairman Santoso and Daeng Koro.

${ }^{26}$ Christopher M. Blanchard, Al-Qaeda: Statements and Evolving Ideology (Congressional Research Service Report for Congress, 2005), 3.

${ }^{27}$ International Crisis Group, Bagaimana Kelompok Ekstrimis Membentuk Kelompok. Baru (Jakarta: International Crisis Group, 2012). 
Group Santoso and Daeng Koro indicated scramble to avoid operation Seagull (operasi camar) performed by the security apparatus in February-March 2015. Comb security apparatus in Poso to fruition with the premature Daeng Koro in the Sakina Jaya, Central Sulawesi, on 3 April 2015. The MIT group has declared itself as a supporter of the Islamic State of Iraq group and Sham (ISIS) leader Abu Bakr al-Baghdadi, thus remaining as head of Ingram became the most sought after and killed on July 18, 2016 in Poso. The end of the main character of Indonesia terrorism networks MIT, MIB, and alertness, making the need for JAT against new transnational nature extreme.

\section{Textual Understanding as a Starting Point}

The pattern of the radical Islamic movement's understanding of the nature of transnational normally associated with the evidence there is no law except from God (lā Hukma illa lillāh), and those who use the law apart from God is a kaafir. ${ }^{28}$ The evidence is certainly becoming the Foundation of the idea that Islam is a religion that is already very complete and plenary to regulate all aspects of life, ${ }^{29}$ including politics. Such a view as being the ideological line of Hasan al-Banna, Sayyid Quthb, Rashid Ridha, Taqiyudin an-Nabhani, and al-Mawdudi.

In the history of early Islamic thought, a proposition the disbelief has been used by a group of Kharijites to judge the Ali bin Abi Talib, 'Amr Ibn Ash, and Mu'aawiyah Ibn Abi Sufyan, Abu Musa al-Ash'ari that do tahkīm (peace) in the battle of siffin on $37 \mathrm{H} / 657 \mathrm{M}$ with lifting the alQur'an above the cutting edge. ${ }^{30}$ The reject tahkim because

\footnotetext{
${ }^{28}$ QS. Al-Maidah ayat 44

${ }^{29}$ QS. Al-Maidah ayat 3

${ }^{30}$ Muhammad Abū Zahrah, Tārìkh al-Madhāhib al-Islämiyah (Cairo: Dār el-Fikr al-'Arābi, tt), 99; Abī Ja’far Muhammad ibn Jarīr al-Tabarī, Tārikh al-Ṭabarī: Tārikh al-
} 
it is considered not in accordance with the law of Allah so out of line Ali in the deliberations of the peace in Daumatul with judging as an infidel of the companions Jandal senior, led by Abdullah Ibn Wahab Al-with a total of 12,000 Rasyidi troops. ${ }^{31}$

The development pattern of thought propaganda by Khawarij groups with various sects in it at least can be understood through the same identity, i.e., restricting religious propositions only on al-Quran and al-Hadith. Therefore, there was a disclaimer of ijma' (consensus of the scholars) and qiyās (analogy) both of which are very close to the use of reason or logic in the determination of the law which is not found in the Qur'an and Hadith al-especially regarding worldly affairs. ${ }^{32}$ Methodology of ta'wil (interpretation against the proposition) with the use of reason or logic it thinks will only make the religion is not pure anymore because contaminated the opinions of men who do not have the Authority set the Shari'ah.

As a result of the law of God as being the line of Muslim Brotherhood ideology Ikhwanul Muslimin (IM) considers only Islamic law is sourced from, rather than sourced from other religions. Such views have fueled the exuberance of the seeds of fanaticism diversity that leads to extremism. ${ }^{33}$ The law of God in the QUR'AN. Al-Maidah verse 44 is understood as a legal entity which has been codified as laws have been codified by Shia clerics or scholars

Rasūl wa al-Muluk, juz III (Kairo: Dār al-Ma’ārif, 1963), 540-543.

${ }^{31}$ Harun Nasution, Theologi Islam, Sejarah Analisa dan Perbandingan (Jakarta: UI Press, 1991), 23; Azyumardi Azra, Pergolakan Politik Islam (Bandung: Mizan, 1999), 112113; Philip K. Hitti, History of The Arabs (London: The Macmilan Press LTD, 1974), 181-183.

${ }^{32}$ Abu Muhammad Ibn Hazm, al-IḤkàm fì UṢ̂ul al-AḤkām, Vol. 1 (Beirut: Dār al-Afaq al-Jadīiah, 1980), 27.

33 Zuhairi Misrawi, Al-Qur'an Kitab Toleransi Inklusivisme, Pluralisme, dan Multikulturalisme (Jakarta: Penerbit Fitrah, 2007), 401. 
of Sunni Islam. The historical context to the descent of this verse concerned Jews punished whip and heated body due to committing adultery and already married. ${ }^{34}$ It is explained that the verse is not related to the establishment of an Islamic State or khilafah system but the Abrahamic religious obligations to implement the law in the holy book itself.

Table. Evidence Of Violence In The Name Of Religion ${ }^{35}$

\begin{tabular}{|c|l|l|}
\hline No & \multicolumn{1}{|c|}{ Dalil (The Proposition) } & \multicolumn{1}{c|}{ Understanding } \\
\hline 1 & QS. Al-Maidah verse 44 & $\begin{array}{l}\text { Comply with the law other than the } \\
\text { law of God is a kaafir }\end{array}$ \\
\hline 2 & QS. Al-Maidah verse 3 & Islam already perfect set all fields \\
\hline 3 & QS. Al-Fath verse 29 & Being tough against the infidels \\
\hline 4 & QS. At-Taubah verse 5 & $\begin{array}{l}\text { Orders to kill, capture, and ferret } \\
\text { out those polytheists (Musyirikin) }\end{array}$ \\
\hline 5 & QS. Al-Baqarah verse 120: & $\begin{array}{l}\text { Jews and Christians have always had } \\
\text { a plan to attack the Muslims }\end{array}$ \\
\hline
\end{tabular}

The method of understanding Dalil theses in textual by rejecting other approaches make this group tends to be exclusive and fanatical. This unfriendly literalist group with the group out of its parts and always think negatively with other groups. Being tough is not a physical attack upon pagan infidels, but an understanding to fight the pagan values in the context of tolerance, that injustice, and dictatorship in the community.

Scholars of nationalism with accept Pancasila as the the state ideology Indonesia is a middle stance taken to maintain the unity of Indonesia, while keeping the existence of religion. NU and Muhammadiyah as a leading organization in the defense of Indonesia nationalism isn't interested in doing formalisasi of Islamic law in the life of nationality and statehood as the enforcement of

\footnotetext{
${ }^{34}$ Imām al-WāHịi, Asbāb al-Nuzūl (Kairo: Dār al-Ḥadīth, 2003), 150.

${ }^{35}$ Nasaruddin Umar, Deradikalisasi Pemahaman Al-Qur'an dan Hadis (Jakarta: Elex Media Komputindo, 2014), 83-232.
} 
Islamic law in the public space, State administration, and State administration, including private law family such as marriage, inheritance, and banking. NU on its own before the independence through the 11th Congress in 1936 in Banjarmasin confirmed Indonesia was already as the Islamic country because its people are predominantly Muslim, and there is no ban on running it though the Protestant Kingdom led by the Netherlands. ${ }^{36}$ The relationship of religion and the State by scholars NU considered in connection with maintaining Indonesia nationalism accommodating without discriminating of religion, tribe, and inter-group relations. Politics as the source of radicalism as an opinion of Angel Rabasa, muted by NU cleric with a fatwa acceptance of Pancasila as the ground state.

Battle of ideas between nationalism and religion always leads to two main issues, namely the relation of muslim versus non-Muslims and law of God versus law of man. The Foundation should be built is the realization that Islam as a religion of humanity. The theological category understanding of the changes to be done consists of Islamic relations with non-Muslims, the law of God in the religions, Islam is rahmatan lil ' ālamīn, as well as the paradigm of jihad and war. $^{37}$

The selection of texts that are very popular among radical Islam in terms of the relationship between Islam with other religions is QS. Al-Baqarah verse 120: "Jews and Christians will not be glad to you until you follow their religion. Say: "Verily, Allab's instructions that the instructions (correct)". And behold, if ye follow the whims of those after knowledge came unto thee, God is no longer a protector and helper for you.".

${ }^{36}$ Jimmy Oentoro, Indonesia Satu, Indonesia Beda, Indonesia Bisa (Jakarta: Gramedia Pustaka Utama, 2010), 167.

${ }^{37}$ Materi Pembinaan Keagamaan di LP Cipinang, 2010-2011. 
There are 3 (three) problem over the verse used to combat or suspect among the non-Muslims. First, the emergence of the perception that people outside Islam especially Christians and Jews as the eternal enemy, which corroborated the existence of some verses that condemned the behavior of the Jews and Christians over the Prophet Mohammed and their followers. Second, the relationship of hostility came into force in a period not limited that looked at all of the Jews and the Christians as enemies. Third, the loss of attention to other verses calling for tolerance so that aspects of the Qur'an which consists of thousands of verses as generalized in verse only certain.

Historical context in coloring the emergence of religious texts certainly have different shades if linked in space cooperation in the fields of education, economics, politics, culture, and more. So because the text relating to the cease-fire and the transfer of the Qibla direction. Hostility against Jews and Christians that are generalizable to all areas it will be contrary to the paragraph which States the importance of understanding the diversity of tribes, Nations, and religions.

Understanding the underlying religious movement on the obligation to uphold the law, already done by Wahabisme sponsored by Saudi Arabia by doing the institutionalization of religious doctrine. ${ }^{38}$ The effects, the law of God considered a law that stems from Islam to negate the other religions. Islamic law also undergo specific as a law passed down to certain groups, such as Islamic law which codified a Sunni cleric then considered not as God's law by Shia. The fact that it can be seen from what was once practiced among the

${ }^{38}$ Khaled Abou el-Fadl, The Great Theft: Wrestling Islam from the Extremists (New York: harperSan Fransisco, 2005), 45-94. 
Khawarij with declared Ali bin Abu Tholib and Muawiya as infidels.

Pay Attention To The QS. Al-Maidah verse 44 and 47 explained the existence of laws that governed not just Islamic law, but also the law of God in the book of the Torah and the Gospels. If such a view makes 47 (forty-seven) convict terrorism LP Cipinang from 58 (fifty-eight) person, and the ex-convict terrorism can accept Pancasila as the source of law in Indonesia because the concept of Pancasila is drawn from Islamic religious text by framers.

Table 2. Evidence of the relationship of Islam and the Principles of Pancasila $^{39}$

\begin{tabular}{|c|c|c|}
\hline No & Precepts of Pancasila & $\begin{array}{c}\text { Dalil Islam (The Islamic } \\
\text { Proposition) }\end{array}$ \\
\hline 1 & $\begin{array}{l}\text { Believe in the one } \\
\text { supreme God }\end{array}$ & $\begin{array}{l}\text { And your God is one the God Almighty } \\
\text { (QS. Al-Baqarah: } 163 \text { ) }\end{array}$ \\
\hline 2 & $\begin{array}{l}\text { Justice and civilized } \\
\text { humanity }\end{array}$ & $\begin{array}{l}\text { O you who believe! Be upright for Allah, } \\
\text { bearers of witness with justice, and let } \\
\text { not hatred of people incite you not to act } \\
\text { equitably; act equitably, that is nearer to piety, } \\
\text { and be careful of (your duty to) Allah; surely } \\
\text { Allah is Aware of what you do. (QS. Al- } \\
\text { Maidah: 8) }\end{array}$ \\
\hline 3 & The unity of Indonesia & $\begin{array}{l}\text { The believers are but brethren, therefore make } \\
\text { peace between your brethren and be careful of } \\
\text { (your duty to) Allah that mercy may be had } \\
\text { on you (QS. Al-Hujurat: 10) }\end{array}$ \\
\hline 4 & $\begin{array}{l}\text { The democracy led } \\
\text { by understanding } \\
\text { among honorable } \\
\text { representatives from } \\
\text { the parliament house }\end{array}$ & $\begin{array}{l}\text { Take counsel with them in the affair; so } \\
\text { when you bave decided, then place your trust } \\
\text { in Allab; surely Allab loves those who trust. } \\
\text { (QS. Al-Imran: 159) }\end{array}$ \\
\hline 5 & $\begin{array}{l}\text { Social justice for all the } \\
\text { people of Indonesia }\end{array}$ & $\begin{array}{l}\text { Surely Allah enjoins the doing of justice and } \\
\text { the doing of good (to others) and the giving to } \\
\text { the kindred (QS. An-Nahl:90) }\end{array}$ \\
\hline
\end{tabular}

${ }^{39}$ Douglas E. Remagee, Pemahaman Abdurrabman Wabid Tentang Pancasila dan Penerapannya Dalam Era Paska Azaz Tunggal (Yogyakarta: LKiS, 1994). 
Quraish Shihab explains that people who obey the law by using the Torah and the Gospels in the Qur'an is called Ablul Kitäb as much as 31 times, $A l-Y a b \bar{d}$ as much as 8 times, the $A n-\mathrm{NaS}$ àra as many as 14 times, and Bani Isräil as many as 41 times. ${ }^{40}$ People of the book or the mention of such a type is defined as a concept that gives recognition to the religion of Islam which has outside of Scripture. The attitude of this recognition was meant to give the recognition of the right of existence in running their respective religious rules in the sphere of nationality. In Arabic, the term vocabulary that have meaning among other Nations qaum and sya'b. Qaum said in the Qur'an is called as much as 322 times, as in QS. HUD v. 63-84. While the word sya'b only found in 1 paragraph as in QS. Al-Hujurat verse 13.

The term nationality is an overview of the characteristics against the unity of the people of the same descent, culture, language, and the roots of its history at a particular location. In common traits against humans so it can be called a nation begins to develop in the 18th century in Europe, and is undergoing a transformation to the ideology of the Islamic world. The dissemination of the national ideology developed over the aggression of Napoleon Bonaparte to Egypt in July 1978 the propagandize themselves as devout Muslims. Through the dissemination of propaganda by pamphlet 36,000 forces beginning with the phrase "Bismillahirrahmanirrahim" to show as a brother.

Strategy based on similarity of origin awaken consciousness and make some Muslims feel that nationalism became a cause of the splitting of the Islamic world. For groups of such Islamism HTI, nationalism is considered primordialism and fanaticism of

${ }^{40}$ M. Quraish Shihab, Wawasan Al-Qur'an: Tafsir Maudhu'i atas Pelbagai Persoalan Umat (Bandung: Penerbit Mizan, 2003), 348. 
nationalities (ashabiyab) which is rather forbidden (baram). ${ }^{41}$ That opinion into political views the majority of Islamic groups radical in Indonesia. The Group was sticking to the principle of the unity of the people based on the bonds of aqidah or Islamic ideology, not the bonds of nationhood. It thus refers to the QS. Al-Hujurat, verse 10 real believers are brothers.

The development of the ideology of the real national anthem has been performed by the Prophet Muhammad in the process of building a new society of the city of Yatsrib. Modern nationalism that marked by the preparation of the Constitution Charter of Madinah (Mitsaq al-Medina) to bind the entire community of Medina without discriminating of religion, tribe or social class. The composition of the communities of Medina at that time consisted of the Khazraj tribe Auz and some embraced Islam, and tribal Quraizhah, Nadhir, and the Qaynuqa who embrace Jews. ${ }^{42}$ The Medina Charter went into effect for the entire tribe in order to defend the sovereignty of the city of Yatsrib which was later changed to the city of Medina.

Strategies of Prophet Muhammad in Medina has similarities with the life of the Indonesia nationality did not apply the law based on the Constitution of a particular religion for the whole tribe, but implementing the Constitution on the basis of a mutual agreement with the spirit of the principles of the equation. The togetherness of the community based on the territorial aspect of defending showed a State Defense that was built by the community of Medina.

Nationality or ideology of nationalism has obvious basis in the Qur'an with the inclusiveness to know each

${ }^{41}$ M. Kusman Sadik, "Nasionalisme dan Separatisme Haram!” (31 Maret 2013), http://www.hizbut-tahrir.or.id/2013/03/31/nasionalisme-dan-separatisme-haram/ (diakses 10 Pebruari 2014).

${ }^{42}$ Mun'im A. Sirry, Membendung Militansi Agama: Iman dan Politike dalam Masyarakat Modern (Jakarta: Erlangga, 2003), 175. 
other's identity with one another. Certainly the existence of nationality will be found promoting diversity in terms of religion, tribe, colour, social status, and other differences with restricted awards through devotion, namely the humanizing of man by not harassing each other. Intersection between nationality with Islamic can be seen on the principle that it should uphold. A nation demands unity of society (al-ummab), the protection of society (al-adalah), the principle consultative (al-syura), and equality of treatment (al-musawah).

Nationalism is the look of the concept that was built by the Prophet Muhammad to pay attention to the interests of the Union society (al-ummah al-wabidah). Muslim society in Indonesia since its development already knows the meaning of sisterhood/brotherhood is not simply on the basis of civil religion (ukhuwah Islamiyah) but also the brotherhood of compatriots (ukhuwah wathaniyah), and fellow fraternity of man (ukhuwah basyariyah). It is thus formulated by the founder Nations with ties of Pancasila.

Violence in the name of religion that still bloom occurred in Indonesia indicated that the attitude and behaviour of most community Indonesia no longer in accordance with the principles of Pancasila. Society tends to choose violence or strong penalties in the face of difference. The Act thus fostering religious intolerance, the burning of houses of worship, religious and frustrated with the ideology of Islam became the religion of the network terrorism.

Indonesia's muslim community many don't perceive that Pancasila was the religious principles of Islam. Epistemology in Islamic law (ushul fiqib), Pancasila as well as al-kulliyat al-khams, namely the basic principle of the purpose of the enforcement of Islamic law. Five principles of Islamic law is the protection of religion ( $h i f z h$ din), the protection of inhabitants ( $h i f_{z} h$ al-nafs), protection of offspring ( 
nasl), protection of intellect (bif₹̧ al'aql), the protection of property (bif:h mal).

Al-kulliyat al-khams in the context of Indonesia is already reflected in the formulation of Pancasila. Precepts (sila) basic State which is native to Indonesia, the nation's cultural products already provide protection of religion on the first precept. Protection and humanitarian aspects in the sila. Protection of offspring as a form of citizenship rights in the third sila. Reason and protection of freedom of Assembly gathered in the fourth sila. While the protection of property and access to economic resources is reflected in the fifth sila.

Pancasila is the Foundation of the norm over the laws prevailing in Indonesia. It therefore implies the enforcement and application of Islamic jurisprudence should not be contrary to the values of Pancasila, that is the value of the divinity, humanity, unity, deliberation, and justice. Islamic law placed as a source of formation of national laws that interact with other religions. Pancasila as the film placed to establish sect of Islam in Nusantara in order to develop the civilization of Indonesia and a peaceful world civilization.

\section{D.Conclusion}

A peace meeting between nationalism with religion in Indonesia with tangible success formula of Pancasila. Promoting diversity of characters get position a good award in order to create synergiy between the teaching of Islam with customs or local wisdom society Archipelago. It forms a social system which then mapped out the national identity itself. Formulations of Islam and the country that is formed into a unitary State of the Republic of Indonesia (NKRI).

NKRI is the country base their interaction patterns of the society being open, friendly, and environmentally 
friendly culture. Therefore, Islam as a religion that synergize with the culture, uphold the attitude of the middle way or moderation (tawasuth). The pattern of Islam in Indonesia as darussalam creates implementation of Pancasila and NKRI, as the essence of the teachings of Islam ablussunnab wal jama'ah. The collaboration between the Pancasila and NKRI, it animates the characteristics of Indonesia's peaceful Nations, fostering diversity, as well as being able to cooperate in promoting diversity.

The three main pillars that support the identification of the potential success of the transnational movement of radicalism is by combining the religious approach with national approaches through cross-cutting cooperation. Partnerships must be supported with the utilization of structural strength, and Islamic authorities. The synergy of cooperation undertaken between Kemenkumham with BNPT as well as ministry of Religious Affairs has made some radical network core figures admit mistakes and build a sense of nationalism against NKRI, such as Ali Imron, Nasir Abas, and Umar Patek. 


\section{REFERENCE}

A. Maftuh Abegebriel, dkk (Ed). Negara Tuhan: The Thematic Encyclopedia (Yogyakarta: Pustaka Pelajar, 2003)

A. Martha Ackelsberg. "Identity Politics, Political Identities: Thoughts toward a Multicultural Politics", Frontiers: A Journal of Women Studies, Vol. 16 No. 1, 1996.

A.M. Fatwa. Satu Islam Multi Partai (Bandung: Mizan Media Utama, 2000)

Abdul Munir Mulkhan. Runtubnya Mitos Politik Santri; Strategi Kebudayaan Dalam Islam (Yogyakarta: Sipress, 1999)

Abdullah Ahmed al-Naim. Dekonstruksi Syariah (Yogyakarta: LKiS, 1994), 7; Muhammad Iqbal, Fiqih Siyasah: Kontekstualisasi Doktrin Politik Islam (Jakarta: GMP, 2007)

Abhisek Singh dan Gopal Thakur. "New Media Technology as Public Sphere for Social Changes: A Critical Study", Journal o Indian Research 1, 2013.

Ahmad Najib Burhani. "Ethnic Minority Politics in Jakarta's Gubernatorial Election", Perspective, ISEAS Yusof Ishak Institute, Nomor 39, 9 Juni 2017.

Ahmad Syafi'i Mufid. Perkembangan Paham Keagamaan Transnasional di Indonesia (Jakarta: Puslitbang Kehidupan Keagamaan Balitbang dan Diklat Kementerian Agama RI, 2011).

Alexandra Maryanski dan Jonathan Turner. The Social Cage:

Human Nature and the Evolution of Society (Stanford:

Stanford University Press, 1992)

Ali Imron. Ali Imron Sang Pengebom, Cet. 1 (Jakarta: Republika, 2007) 
Al-Zastrouw Ng. Gerakan Islam Simbolik: Politik Kepentingan FPI (Yogyakarta: LKiS, 2006)

Amin Rais. Cakerawala Islam (Bandung, Mizan, 1987).

Amy Gutmann. Identity in Democracy (Princeton, New Jersey: Princeton University Press, 2003).

Anies Rasyid Baswedan. "Political Islam in Indonesia, Present and Future Trajectory", Asian Survey The Regent of the University of California, Vol. XLIV, Nomor 5, September/Oktober (2004)

Anthony Bubalo dan Greg Fealy. Joining the Caravan? Middle East, Islamism and Indonesia (New South Wales: The Lowy Institute for International Policy, 2005).

Arie Setyaningrum Pamungkas dan Gita Octaviani. "Aksi Bela Islam dan Ruang Publik Muslim: Dari Representasi Daring ke Komunitas Luring", Jurnal Pemikiran Sosiologi UGM, Volume 4 Nomor 2, Agustus 2017.

As'ad Said Ali. Al-Qaeda: Tinjauan Sosial-Politik, Ideologi dan Sepak Terjang (Jakarta: LP3ES, 2014)

Asep Adisaputra. Imam Samudra Berjihad (Jakarta: Grafika Indah, 2006)

Azyumardi Azra. "Fenomena Fundamentalisme Dalam Islam, Survey Historis dan Doktrinal", Jurnal Ulumul Qur'an, No. 3, Vol. IV, 1993.

Azyumardi Azra. Pergolakan Politik Islam: Dari Fundamentalisme, Modernisme hingga Post-Modernisme, Cetakan I, Jakarta: Penerbit Paramadina, 1996)

Bariie Gunter dan Roger Dickinson. News Media in the Arab World (London: Bloomsbury, 2013)

Christopher M. Blanchard. 'Al-Qaeda: Statements and Evolving Ideology (Congressional Research Service Report for Congress, 2005) 
Clifford Geertz. The Religion of Java (Chicago: University of Chicago Press, 1976)

Deliar Noer, et.all. Mengapa Partai Islam Kalah? Perjalanan Politik Islam dari Pra-pemilu'99 sampai Pemilihan Presiden (Jakarta: AlvaBet, 1999)

Deliar Noer. Gerakan Modern Islam di Indonesia 1900-1942 (Jakarta: LP3ES, 1996)

Donatella della Porta dan Sidney Tarrow. Transnational Protest and Global Activism (Oxford: Rowman dan Littelfield Publisher, 2005).

Donny Gahral Adian. "Mencegah Lahirnya Terorisme Negara Indonesia Pasca Bom Bali”, Analisis CSIS, Vol. 32, No. 1, 2003.

Engy Abdelkader. When Islamophobia Turns Violent: The 2016 U.S. Presidential Elections (Georgetown: Georgetown University, 2016).

Farish A. Noor. Yoginder Sikand, dan Martin van Bruinessen, The Madrasa in Asia: Political Activism and Transnatonal Linkages (Amsterdam: ISIM Amsterdam University Press, 2008).

Hani As-Sibai. Balada Jamaah Jihad: Melacak Kiprah Dr. Aiman Az-Zawabiri (Solo: Jazera, 2005)

Herbert Spencer. The Prinsiples of Biology (New York: D. Appleton and Company, 1998).

I. Marion Young. Justice and the Politics of Difference (Princeton: Princeton University Press, 1990)

James J. Fox. "Currents in Contemporary Islam in Indonesia", Harvard Asia Vision 21, 29 April - 1 May 2004.

James M. Lutz dan Brenda J. Luts. Global Terrorism (London: Routledge, 2004) 
Jefrey Ian Ross. "Deconstructing the Terrorism News Media Relationship", Journal Crime, Media, Culture, Vol. 3, No. 2 (2007)

John Hutchinson dan D. Anthony Smith. Etnicity (Oxford: Oxford University Press, 1996)

John L. Esposito, Benturan Antar Peradaban: Citra Kontemporer Islam di Barat (Yogyakarta: Qalam, 2002)

Jurgen Habermas. The Structural Transformation of the Public Sphere: An Inquiry into a Category of Bourgeois Society (Yogyakarta: Kreasi Wacana, 2010)

Khaled M. Abou El Fadl. Selamatkan Islam dari Muslim Puritan, Terj. Helmi Mustofa (Jakarta: Serambi, 2005)

Khaled M. Abou Fadl. Melawan Tentara Tuhan (Jakarta: Serambi Ilmu Semesta, 2003)

Khalil Al-Anani. "Brotherhood Bloggers: A New Generation Voices Dissent”, Arab Insight, 2 (1), 2008.

M. Imdadun Rahmat. Arus Baru Islam Radikal: Transmisi Revivalisme Islam Timur Tengah ke Indonesia (Jakarta: Erlangga, 2005)

M. Linda Alcoff. Identity Politics Reconsidered (USA: Palgrave Macmillan, 2006)

Madeline Storck. "The Role of Social Media in Political Mobilisation: a Case Study of the January 2011 Egyptian Uprising, Dissertation (Scotland: University of St Andrews, 2011)

Majelis Ulama Indonesia. Fatwa Munas VII Majelis Ulama Indonesia (Jakarta: Majelis Ulama Indonesia, 2005); Fatwa MUI Nomor 1-11 Tahun 2005.

Mark Jurgensmayer. Terror in the Mind of God: The Global Rise of Religious Violence (California: University of California Press, 2001) 
Mary Bernstein. "Identity Politics", Annual Review of Sociology, Vol. 31, 2005

Masykuri Abdillah. Islam dan Demokrasi; Respon Intelektual Muslim Indonesia Terhadap Konsep Demokrasi 1966-1993 (Jakarta: Prenadamedia, 2015)

Michelle Penner Angrist. "Mourning in Tunisia: The Frustations of Arab World Boil Over", Foreign Affairs, http://www.foreignaff airs.com/articles/67321/ michelepenner-angrist/morning-in-tunisia (diakses 22 Maret 2017).

Moch Nur Ichwan. "Towards a Puritanical Moderate Islam: The Majelis Ulama Indonesia and the Politics of Religious Orthodoxy," in Martin van Bruinessen (Ed.), Contemporary Developments in Indonesian Islam: Explaining the Conservative Turn, Singapore: ISEAS, 2013.

Muhammad 'Abid al-Jābiri. Qadaya al-Fiker al-'Arābi: al-Masalah al-Thaqäfiyyah (Beirut: Markaz Dirāsah al-Wahidah al-'Arābiyyah, 1994)

Muhammad Haniff Hasan. Teroris Membajak Islam: Meluruskan Jihad Sesat Imam Samudra dan Kelompok Islam Radikal (Jakarta: Grafindi Khazanah Ilmu, 2007).

Nathan John Franklin. "Reproducing Political Islam in Java: The Role of Nahdlatul Ulama and Muhammadiyah Pesantren in the Political Socialisation of Umat", Dissertation (Darwin: Charles Darwin University, 2014)

Nurcholish Madjid. Islam Kemodern dan Keindonesiaan (Bandung: Mizan, 1987)

Oliver Roy. Islam and Resistance in Afghanistan (Cambridge: Cambridge University Press, 1990)

Olivier Roy. Genealogi Islam Radikal, (Yogyakarta: Genta Press, 2005). 
Philip Jenkins. God's Continent Christianity, Islam, and Europe's Religious Crisis (Oxford: Oxford University Press, 2007), 100-104.

Philip Jenkins. The Next Christendom (Oxford: Oxford University Press, 2002)

Philip N. Howard dan M. Hussain Muzammil. Democracy's Fourth Wave? Digital Media and the Arab Spring (Oxford: Oxford University Press, 2013).

Robert Jackson dan George Sorensen. Introduction to International Relations (NewYork: Oxford University Press, 2007)

Rohan Gunaratna. Inside Al-Qaeda, Global Network of Terror (New York: Columbia University Press, 2002).

Sidney Tarrow. The New Transnational Activism (New York: Cambridge University Press, 2005)

Syed Saleem Shahzad, Inside Al-Qaeda and the Taliban (London: Pluto Press, 2011).

Thomas Freidman. The World is Flat: A Brief History of the 21 $1^{\text {st }}$ Century (New York: Farrar, Straus, and Giroux, 2005)

Thomas Olesen. Power and Transnational Activism (New York: Routledge, 2011) 